\title{
Age-Dependent Allozymic Variation in a Natural Population of Lizards
}

\author{
Donald W. Tinkle ${ }^{1}$ and Robert K. Selander ${ }^{2}$
}

Received 2 May 1972-_-Final 13 June 1972

An analysis of allozymic variation at 17 loci in a population of the sagebrush lizard (Sceloporus graciosus) in southern Utah yielded an estimate of genic heterozygosity of 0.028. Seven of the loci were variable, but only one, Est-1, was strongly polymorphic. The observation that the frequency of the common genotype (MM) at the Est-1 locus declined monotonically in successive age classes from 0.74 in hatchlings to 0.58 in adults 4 years old or older suggests that allele frequencies at this locus are not independent of selective influences.

\section{INTRODUCTION}

There has been considerable debate about factors responsible for the maintenance of genetic variability in natural populations. Kimura (1968; see also Kimura and Ohta, 1971), King and Jukes (1969), and others have argued that much, if not most, of the variation in protein structure is a consequence of genetic drift. On this view, most allelic differences in protein structure, including those affecting electrophoretic mobility, are selectively neutral or nearly so. This interpretation has been challenged (Clarke, 1970; Corbin and Uzzell, 1970; Dobzhansky, 1970; Richmond, 1970), and the weight of evidence now favors a hypothesis involving selection as the primary determinant of biochemical polymorphism in natural populations (Prakash et al., 1969; Gottlieb, 1971; Harris, 1971; Uzzell and Pilbeam, 1971; Ayala, 1972; Selander and Johnson, 1973).

This research was supported by NSF grant GB-29141 to D.W.T. and NIH grant GM15769 to R.K.S.

${ }^{1}$ Museum and Department of Zoology, University of Michigan, Ann Arbor, Michigan.

${ }^{2}$ Department of Zoology, University of Texas, Austin, Texas. 
The present study of the sagebrush lizard (Sceloporus graciosus) provides evidence of a selective control of allele frequencies at an esterase locus by demonstrating an age-dependent change in genotypic proportions and contributes an estimate of overall genic heterozygosity in a natural population.

\section{MATERIALS AND METHODS}

The sagebrush lizard ranges from New Mexico and western Texas into Colorado and Wyoming and thence to the West Coast. Over this vast area, it occurs primarily in the sagebrush plains and in the pine-oak-chaparral zone at elevations above $5000 \mathrm{ft}$.

Tinkle (1973) carried out an intensive mark-and-recapture study of this species to obtain information on population age structure, age-specific survivorship, generation time, and reproduction. The study was conducted on two field sites at $7000 \mathrm{ft}$ in the Kolob section of Zion National Park in southern Utah. In each year, all resident lizards on the study areas were marked, so that at the end of the study in 1971 most resident individuals were of known age.

In late summer of 1971 , almost all resident lizards were removed from the study area over a 4-day period. The sample included 109 yearling to 4-year-old individuals known to have hatched on the area and 15 adults that were not marked on the area as hatchlings and thus presumably represented immigrants. Of the latter group, four were 2 years old, seven were 3 years old, and four were 4 years old. These individuals represented $12 \%$ of the resident population. In addition, a sample of 69 lizards was taken from an area of identical habitat about 100 yards from the study site. These unmarked lizards could be assigned to age groups on the basis of size (see Tinkle, 1973, for details). Finally, when hatchlings began to appear in large numbers in early September, a sample of 69 was collected from the margins of the study site. In all, 262 lizards were collected.

In the laboratory, lizard carcasses were individually homogenized (with a Sorvall tissue grinder) in an equivalent volume of buffer $(0.1 \mathrm{M}$ tris, $0.001 \mathrm{M}$ EDTA, and $5 \times 10^{-5} \mathrm{M}$ NADP, with $p \mathrm{H}$ adjusted to 7.0 with $\mathrm{HCl}$ ). The homogenate was centrifuged at $49,000 \times \mathrm{g}$ for $30 \mathrm{~min}$ at $4 \mathrm{C}$ to obtain an aqueous extract. Extracts not electrophoresed immediately after preparation were stored at $-70 \mathrm{C}$.

Techniques of starch gel electrophoresis and protein staining similar to those described by Selander et al. (1971) were employed to demonstrate proteins encoded by 17 structural gene loci. Patterns of phenotypic variation in particular proteins in Sceloporus graciosus were similar to those previously reported for Sceloporus grammicus (Hall and Selander, 1973), Anolis species (Webster et al., 1972), and Uta stansburiana (McKinney et al., 1972). 


\section{RESULTS}

The degree of polymorphism at the 17 loci sampled is low (Table I). Average heterozygosity per locus is only $2.8 \%$, and ten of the loci are monomorphic. Moreover, of the seven polymorphic loci, only esterase- 1 is strongly so, with five alleles recognizable on the basis of the mobility of the enzyme. However, in scoring this locus we combined two of the fast-moving allozymes and two of the slow-moving ones into two classes. This locus, scored for three alleles, contributes $60 \%$ of the average heterozygosity in the population.

The overall frequencies of the three alleles at the Est-1 locus are $0.151 F$, $0.818 M$, and $0.031 S$, and the frequencies of the six possible genotypes agree well with Hardy-Weinberg expectations (Table II). There are no demon-

Table I. Heterozygosity at 17 Loci in a Population of Sceloporus graciosus $^{a}$

\begin{tabular}{|c|c|c|c|c|}
\hline \multirow[b]{2}{*}{ Locus } & \multirow{2}{*}{$\begin{array}{l}\text { Sample } \\
\text { size }\end{array}$} & \multirow{2}{*}{$\begin{array}{l}\text { No. } \\
\text { alleles }\end{array}$} & \multicolumn{2}{|c|}{ Heterozygotes } \\
\hline & & & No. & Proportion \\
\hline$E_{S t-1}$ & 259 & 3 & 73 & 0.282 \\
\hline Got-1 & 262 & 3 & 24 & 0.092 \\
\hline Est -3 & 259 & 2 & 9 & 0.035 \\
\hline $6 P g d$ & 35 & 2 & 1 & 0.029 \\
\hline Pgm-1 & 262 & 2 & 4 & 0.015 \\
\hline Ldh-I & 262 & 2 & 3 & 0.011 \\
\hline Prot-A & 259 & 2 & 2 & 0.008 \\
\hline \multicolumn{2}{|c|}{ Mean heterozygosity } & & & 0.028 \\
\hline
\end{tabular}

"Ten loci are monomorphic: Got-2 $(n=35), M d h-1$ (35), $M d h-2$ (35), $\alpha$ Gpd (35), Idh-1 (35), Ipo (35), Pgi (192), Alb (192), Prot-B (192), and $L d h-2$ (262).

Table II. Genotypic Proportions at the Esterase-1 Locus in Sceloporus graciosus ${ }^{a}$

\begin{tabular}{lrr}
\hline Genotype & $\begin{array}{c}\text { No. } \\
\text { observed }\end{array}$ & $\begin{array}{c}\text { No. } \\
\text { expected }\end{array}$ \\
\hline$F F$ & 10 & 5.8 \\
$M M$ & 176 & 173.5 \\
$S S$ & 0 & 0.2 \\
$F M$ & 57 & 64.0 \\
$F S$ & 1 & 2.4 \\
$M S$ & 15 & 13.1 \\
& & \\
\hline${ }^{a} \chi^{2}{ }_{(4)}=5.15(p>0.1)$.
\end{tabular}


Table MI. Genotypic Frequencies at the Esterase-1 Locus in Five Age Classes of Sceloporus graciosus

\begin{tabular}{|c|c|c|c|c|c|c|c|}
\hline \multirow[b]{2}{*}{ Age class } & \multirow{2}{*}{$\begin{array}{c}\text { No. } \\
\text { individuals }\end{array}$} & \multicolumn{5}{|c|}{ Genotypic frequency $^{a}$} & \multirow{2}{*}{$\begin{array}{c}\text {-Heterozygote } \\
\text { proportion }\end{array}$} \\
\hline & & $F F$ & $M M$ & $F M$ & $F S$ & $M S$ & \\
\hline Hatchling & 69 & 0.029 & 0.739 & 0.203 & 0.014 & 0.014 & 0.232 \\
\hline Yearling & 79 & 0.025 & 0.684 & 0.228 & 0.000 & 0.063 & 0.291 \\
\hline 2-year-old & 50 & 0.040 & 0.680 & 0.180 & 0.000 & 0.100 & 0.280 \\
\hline 3-year-old & 30 & 0.100 & 0.633 & 0.223 & 0.000 & 0.033 & 0.267 \\
\hline 4-year-old and older & 31 & 0.032 & 0.581 & 0.290 & 0.000 & 0.097 & 0.387 \\
\hline Pooled & 259 & 0.023 & 0.672 & 0.246 & 0.009 & 0.049 & 0.282 \\
\hline
\end{tabular}

${ }^{a}$ No $S S$ homozygotes observed.

strable differences in genotypic or genic frequencies between subsamples of individuals collected in the study area and 100 yards from the study area. Nor do the 109 true residents and the 15 presumed immigrants from the study area differ significantly. We therefore feel confident in concluding that the combined sample represents a genetically homogeneous population.

Although significant heterogeneity in genotypic proportions at the Est-1 locus among age classes cannot be demonstrated $\left(\chi_{(12)}^{2}=8.85\right.$, with $F S$ and $M S$ categories combined), a suggestion of age-dependent change is provided by the monotonic decrease in the frequency of the major genotype $(M M)$ from 0.739 in hatchlings to 0.581 in the 4-year-old and older age class (Table III). [By weighted regression analysis, with proportions transformed to arcsin values, in degrees; $F_{(1,3)}=45.95 * *(0.005<p<0.01)$.] The second most common genotype $(F M)$ tends to increase with age, but this variation is not significant by weighted regression analysis $\left[F_{(1,3)}=1.26(p<0.25)\right]$. Hence no one genotype contributes a compensatory increase as the frequency of $M M$ declines. As a consequence of decreasing frequency of the $M M$ genotype, the proportion of heterozygotes increases with age, from 0.232 in hatchlings to 0.387 in 4-year-old and older individuals.

All available animals were scored at six of the seven polymorphic loci (Table I), but, unfortunately, the rarity of heterozygotes at all loci except Est-I precludes further analysis. It is apparent, however, that there is no general increase in heterozygote frequency with age at other loci.

\section{DISCUSSION}

The apparent systematic age-dependent decline in frequency of the most common genotype at the Est-I locus, with a concomitant increase in the frequency of heterozygotes at this locus, is not readily compatible with the 
hypothesis that the alleles at this locus are selectively neutral. At present, there is no way that we can be certain that it is the alleles observed that are solely responsible for the fitness of their carriers. Selection could act either directly on the esterase-1 phenotype or on an inversion segment (supergene) with which the Est-I locus is perhaps associated (see discussions in Prakash and Lewontin, 1968; Kojima et al., 1970; Mukai et al., 1971); in the latter case, it would be reasonable to conclude that the linkage disequilibrium itself is maintained by selection. In any event, the data suggest the hypothesis that lizards of some or all genotypes have a survivorship advantage over the $M M$ homozygote, inasmuch as the frequency of the $M M$ homozygote declines by more than $20 \%$ between hatching and old age. The fact that $74 \%$ of the hatchlings are homozygous for the $M$ allele suggests a compensating advantage for the genotype, perhaps during embryonic development. Or carriers of that genotype may be slightly more fecund than animals with other genotypes. In any event, these data seem to provide an additional bit of evidence suggesting that selection is involved in the determination of allele frequencies at structural gene loci.

Selection has been implicated in the maintenance of esterase polymorphisms in other organisms, the catostomid fish Catostomus clarkii (Koehn, 1969, 1970) and the freshwater fish Notropis stramineus (Koehn et al., 1971). Age-dependent mortality in esterases has not been demonstrated for any organism, but Fujino and Kang (1968) found a linear age-dependent change in deviations from Hardy-Weinberg expectations at the transferrin locus in the skipjack tuna (Katsuwonus pelamis).

The level of variability in the population of Sceloporus graciosus sampled is relatively low, with only one locus strongly polymorphic. It is unlikely that this low variability can be attributed to drift due to small effective population size or to isolation from gene flow from adjacent populations. The species has a fairly wide ecological amplitude, occurring in grasslands, sagebrush plains, and areas with moderate tree coverage, and it is widely distributed and abundant over much of the western United States. Tinkle (1973) has suggested that the population sampled in the present study is perhaps more stable in size, density (average of 85 per acre), and age structure than any other lizard population yet studied. Possibly this stability reflects rather low environmental heterogeneity which, in turn, results in selection for homozygosity at many loci. However, with only a single sample, little can be said about the overall variability of the species. The congeneric species Sceloporus grammicus of Mexico is perhaps more polymorphic, with an average heterozygosity of $7 \%$, but heterozygosity varies from $2 \%$ to $13 \%$ in different populations, being lowest in those isolated on small mountain peaks or ranges (Hall and Selander, 1973). Uta stansburiana, a small iguanid lizard that essentially replaces $S$. graciosus at low elevations over much of the western United States, apparently 
also is more polymorphic ( $5 \%$ heterozygosity; McKinney et al., 1972), and it may be significant that detailed field studies of this species (Tinkle, 1967; Turner et al., 1970) have revealed considerable year-to-year fluctuation in population size.

\section{ACKNOWLEDGMENTS}

Assistance in the demographic studies in Utah was provided by members of the Tinkle family; G. A. Hoddenbach assisted in collecting specimens; Y. J. Kim and C. O. McKinney provided laboratory assistance; and Y. Hiraizumi provided statistical advice. We thank R. D. Milkman and S. Prakash for reviewing the manuscript.

\section{REFERENCES}

Ayala, F. J. (1972). Darwinian versus non-Darwinian evolution in natural populations of Drosophila. Proc. Sixth Berkeley Symp. Math. Stat. Prob. (in press).

Clarke, B. (1970). Darwinian evolution of proteins. Science 168:1009.

Corbin, K. W., and Uzzell, T. (1970). Natural selection and mutation rates in mammals. Am. Naturalist 104:37.

Dobzhansky, T. (1970). Genetics of the Evolutionary Process, Columbia University Press, New York.

Fujino, K., and Kang, T. (1968). Transferrin groups of tunas. Genetics 59:79.

Gottlieb, L. D. (1971). Gel electrophoresis: New approach to the study of evolution. BioScience $21: 939$.

Hall, W. P., and Selander, R. K. (1973). Hybridization in karyotypically differentiated populations of the Sceloporus grammicus complex (Iguanidae). Evolution (in press).

Harris, H. (1971). Protein polymorphism in man. Can. J. Genet. Cytol. 13:381.

Kimura, M. (1968). Evolutionary rate at the molecular level. Nature 217:624.

Kimura, M., and Ohta, T. (1971). Theoretical Aspects of Population Genetics, Princeton University Press, Princeton, N.J.

King, J. L., and Jukes, T. H. (1969). Non-Darwinian evolution. Science 164:788.

Koehn, R. K. (1969). Esterase heterogeneity: Dynamics of a polymorphism. Science 163: 943.

Koehn, R. K. (1970). Functional and evolutionary dynamics of polymorphic esterases in catostomid fishes. Trans. Am. Fish. Soc. 99:219.

Koehn, R. K., Perez, J. E., and Merritt, R. B. (1971). Esterase enzyme function and genetical structure of populations of the freshwater fish, Notropis stramineus. Am. Naturalist 105:51.

Kojima, K., Gillespie, J., and Tobari, Y. N. (1970). A profile of Drosophila species' enzymes assayed by electrophoresis. I. Number of alleles, heterozygosities, and linkage disequilibrium in glucose-metabolizing systems and some other enzymes. Biochem. Genet. 4:627.

McKinney, C. O., Selander, R. K., Johnson, W. E., and Yang, S. Y. (1972). Genetic variation in the side-blotched lizard (Uta stansburiana). Stud. Genet. 7:307 (Univ. Texas Publ. 7213).

Mukai, T., Mettler, L. E., and Chigusa, S. I. (1971). Linkage disequilibrium in a local population of Drosophila melanogaster. Proc. Natl. Acad. Sci. 68:1065.

Prakash, S., and Lewontin, R. C. (1968). A molecular approach to the study of genic heterozygosity in natural populations, III. Direct evidence of coadaptation in gene arrangements of Drosophila. Proc. Natl. Acad. Sci. 59:398. 
Prakash, S., Lewontin, R. C., and Hubby, J. L. (1969). A molecular approach to the study of genic heterozygosity in natural populations. IV. Patterns of genic variation in central, marginal and isolated populations of Drosophila pseudoobscura. Genetics 61:841.

Richmond, R. C. (1970). Non-Darwinian evolution: A critique. Nature 225:1025.

Selander, R. K., and Johnson, W. E. (1973). Genetic variation among vertebrate species. Proc. XVII Int. Congr. Zool. (in press).

Selander, R. K., Smith, M. H., Yang, S. Y., Johnson, W. E., and Gentry, J. B. (1971). Biochemical polymorphism and systematics in the genus Peromyscus. I. Variation in the old-field mouse (Peromyscus polionotus). Stud. Genet. 6:49 (Univ. Texas Publ. 7103).

Tinkle, D. W. (1967). The life and demography of the side-blotched lizard. Misc. Publ. Mus. Zool. Univ. Mich., No. 132.

Tinkle, D. W. (1973). A population analysis of the sagebrush lizard, Sceloporus graciosus, in southern Utah. Copeia (in press).

Turner, F. B., Hoddenbach, G. A., Medica, P. A., and Lannom, J. R. (1970). The demography of the lizard, Uta stansburiana Baird and Girard, in southern Nevada. J. Anim. Ecol. 39:505.

Uzzell, T., and Pilbeam, D. (1971). Phyletic divergence dates of hominoid primates: A comparison of fossil and molecular data. Evolution 25:615.

Webster, T. P., Selander, R. K., and Yang, S. Y. (1972). Genetic variability and similarity in the Anolis lizards of Bimini. Evolution (in press). 